\title{
Assessment of access to first contact in the perspective of professionals
}

\author{
Avaliação do acesso de primeiro contato na perspectiva dos profissionais \\ Evaluación del acceso de primer contacto en la perspectiva de los profesionales
}

Glaucia Margarida Bezerra Bispo'
ORCID: 0000-0002-2633-002X

Eduarda Maria Duarte Rodrigues' ORCID: 0000-0003-4907-7319

Amanda Cordeiro de Oliveira Carvalho" ORCID: 0000-0003-4274-9960

Kenya Waleria de Siqueira Coêlho Lisboa' ORCID: 0000-0001-6589-5464

Roberto Wagner Júnior Freire Freitas"II ORCID: 0000-0001-9295-1177

Marta Maria Coelho Damasceno'v ORCID: 0000-0003-4461-0145

'Universidade Regional do Cariri. Crato, Ceará, Brazil. "Secretaria Municipal de Saúde. Juazeiro do Norte, Ceará, Brazil.

"'Fundação Oswaldo Cruz. Fortaleza, Ceará, Brazil. "Universidade Federal do Ceará. Fortaleza, Ceará, Brazil.

How to cite this article: Bispo GMB, Rodrigues EMD, Carvalho ACO Lisboa KWSC, Freitas RWJF, Damasceno MMC. Assessment of access to first contact in the perspective of professionals.

Rev Bras Enferm. 2020;73(3):e20180863.

doi: http://dx.doi.org/10.1590/0034-7167-2018-0863

Corresponding author:

Glaucia Margarida Bezerra Bispo

E-mail: glauciambbispo@hotmail.com

EDITOR IN CHIEF: Antonio José de Almeida Filho ASSOCIATE EDITOR: Rafael Silva

Submission: 11-04-2018

Approval: 05-02-2019

\section{ABSTRACT}

Objectives: to evaluate the "access to first contact" attribute, from the perspective of Primary Care Health professionals. Methods: an evaluative and cross-sectional study, carried out from February to March 2017. The sample consisted of 163 health professionals, of both genders, who worked in the basic care of the Municipality of Juazeiro do Norte, Ceará. Access to first contact was evaluated by the Primary Care Assessment Tool (PCATool). The 6.60 mark was used as the cut-off point for the evaluated attribute. Results: access to first contact reached a score of 3.3, denoting a low degree of orientation for Primary Health Care. Nurses were the ones who evaluated the attribute more negatively $(p=3.2)$. Conclusions: access to first contact obtained a low score, pointing to the fragility of the Family Health Strategy as a gateway to the Brazilian Unified Health System (Sistema Único de Saúde).

Descriptors: Health Evaluation; Access to Health Services; Primary Health Care; Family Health Strategy; Health Personnel.

\section{RESUMO}

Objetivos: avaliar o atributo "acesso de primeiro contato", na perspectiva dos profissionais da Atenção Primária à Saúde. Métodos: estudo avaliativo e transversal, realizado no período de fevereiro a março de 2017. A amostra foi composta por 163 profissionais de saúde, de ambos os sexos, que trabalhavam na atenção básica do Município de Juazeiro do Norte, Ceará. O acesso de primeiro contato foi avaliado pelo instrumento Primary Care Assessment Tool (PCATool). Foi empregada a marca de 6,60 como ponto de corte para o atributo avaliado. Resultados: o acesso de primeiro contato alcançou escore de 3,3, denotando um baixo grau de orientação para a Atenção Primária à Saúde. Os profissionais enfermeiros foram os que avaliaram de modo mais negativo o atributo $(p=3,2)$. Conclusões: $o$ acesso de primeiro contato obteve baixo escore, apontando a fragilidade da Estratégia Saúde da Família como porta de entrada do Sistema Único de Saúde.

Descritores: Avaliação em Saúde; Acesso aos Serviços de Saúde; Atenção Primária à Saúde; Estratégia Saúde da Família; Pessoal de Saúde.

\section{RESUMEN}

Objetivos: evaluar el atributo "acceso de primer contacto", en la perspectiva de los profesionales de la Atención Primaria de Salud. Métodos: el estudio de evaluación e transversal, realizado en el período de febrero a marzo de 2017. La muestra fue compuesta por 163 profesionales de salud, de ambos sexos, que trabajaban en la atención básica del Municipio de Juazeiro do Norte, Ceará. El acceso de primer contacto fue evaluado por el instrumento Primary Care Assessment Tool (PCATool). Se empleó la marca de 6,60 como punto de corte para el atributo evaluado. Resultados: el acceso de primer contacto alcanzó una puntuación de 3,3, denotando un bajo grado de orientación para la Atención Primaria de Salud. Los profesionales enfermeros fueron los que evaluaron de modo más negativo el atributo $(p=3,2)$. Conclusiones: el acceso de primer contacto obtuvo bajo puntaje, apuntando a la fragilidad de la Estrategia Salud de la Familia como puerta de entrada del Sistema Único de Salud (Sistema Único de Saúde).

Descriptores: Evaluación en Salud; Acceso a los Servicios de Salud; Atención Primaria de Salud; Estrategia Salud de la Familia; Personal de Salud. 


\section{INTRODUCTION}

Assessment of Primary Health Care (PHC) is a concern and, therefore, a priority for the Ministry of Health $(\mathrm{MoH})$, which develops relatively research strategies in the country, with the intention of evaluating the results achieved, among them being the organization, provision and quality of health services.

The implementation of the Family Health Strategy (FHS) as the structuring axis of the reorganization of the Brazilian Unified Health System (SUS - Sistema Único de Saúde), based on PHC, favors major advances in terms of greater access, higher quality of services and reconfiguration ways of producing health care in the territory ${ }^{(1)}$. In the Brazilian territory, FHS should be the main gateway to the health service ${ }^{(2)}$.

PHC comprises an articulated and integrated set of attributes inherent to health services: access to first contact, comprehensiveness, longitudinality, coordination, family and community orientation, and cultural competence ${ }^{(3)}$.

It is possible to evaluate each attribute separately, although all are interrelated, both in the care practice and in the individual or collective practice, considering that the greater the presence and the extension of an attribute, the stronger the orientation for $\mathrm{PHC}^{(4-6)}$.

In this context, the access to first contact is distinguished as an attribute consisting of two components: structure (accessibility) and performance (use or access). The structure favors the entrance of people to the health service, considering geographic and organizational aspects, as well as the capacity to produce and respond to the needs of the population. Performance refers to how people perceive accessibility and use these services to achieve better health outcomes, and is not restricted to just entering the service ${ }^{(7)}$.

It was decided to include in this study the definition of "access to first contact" as the first resource used by users, having needs (new or old problems), becoming a gateway to the health system, anchored in the complexity of the concept of access, in the absence of consensus, its comprehensiveness, literature and in the use of the theoretical tool and model adopted by Starfield ${ }^{(3,5,8)}$.

The benefits of effective access to first contact directly influence the reduction of morbidity and mortality, the number of hospital admissions and unnecessary referrals. Nevertheless, lack of effectiveness of accessibility may make it difficult to resolve the health problems of the assisted population and hamper the performance of the service itself(9).

Studies $^{(9-13)}$ show that although there are positive changes in the primary level of care, access remains one of the main challenges for health services. However, in the international context, access to first contact presents with a score above the cutoff point ${ }^{(14-15)}$. This attribute runs through a range of issues, such as embracement, humanization of care offered, adequacy between the supply and demand of services, including availability and geographical accessibility ${ }^{(13)}$.

There are different ways to evaluate PHC attributes. However, PCATool is one of the most used means, since it is a tool already validated in Brazil. In the context of the Northeastern Region, there are few studies that sought to evaluate access to first contact, especially in Ceará, the stage for the elaboration and origin of two relevant strategies, such as the Programa de Agentes Comunitários de Saúde (Community Health Agents Program) and the FHS.
The present study, therefore, differs from the others, since it presents information that is non-existent and necessary for the SUS assessment as a gateway, from the perspective of the three professional categories of higher education (nurse, physician and dentist) of the family. The assessment of access from the point of view of these can reveal the functional and structural elements in the organization of their actions, as well as reveal the possible paths to be covered in order to guarantee coverage, universal access and comprehensive and integrated care for the population SUS user.

\section{OBJECTIVES}

To evaluate the "access to first contact" attribute, from the perspective of Primary Care Health professionals.

\section{METHODS}

\section{Ethical aspects}

This research considered, in all its stages, the ethical principles that guide the research involving human beings, described and established by Resolution 466/2012. The study was approved by the Research Ethics Committee of the Universidade Regional do Cariri (URCA).

\section{Design, place of study and period}

Evaluative research, with a quantitative approach and crosssectional design, developed in a Doctoral thesis of the Postgraduate Nursing Program of the Universidade Federal do Ceará. The study was carried out in $63 \mathrm{PHC}$ health facilities in the municipality of Juazeiro do Norte, Ceará, Brazil, in the months of February and March 2017. A checklist containing 22 items, called STROBE Statement, was also used to guide the methodology, with recommendations on what should be included in a precise and complete description of cross-sectional studies ${ }^{(16)}$.

Juazeiro do Norte is in the central area of the Cariri Metropoli$\tan$ Region, in the south of the state of Ceará, occupying an area of $248 \mathrm{~km}^{2}$ with an estimated population of 266,022 thousand inhabitants and a population density of $1,006.91 \mathrm{inhab} . / \mathrm{Km}^{2}(17)$. For administrative and operational purposes, the Municipality was divided into seven districts and has at its first level of care 63 Family Health Teams. Of these, 38 have an Oral Health team, 12 traditional care teams, called Community Health Agent Teams, promoting a coverage of $75 \%$ of the population ${ }^{(18)}$.

\section{Sample, inclusion and exclusion criteria}

A total of 163 professionals participated: 40 dentists, 63 nurses and 60 physicians working at FHS. It was used as inclusion criterion to be in the team for at least one year, considering that time is a determining factor for the establishment of links between professionals and users. The exclusion criterion was the fact of being away for vacation or medical leave reasons. Among the total population of the research (169 professionals working in the research period), only 06 (six) converged with the exclusion criteria. 


\section{Study protocol}

Data were collected through a tool composed of two parts. The first contained data for sociodemographic characterization, academic training and professional experience, where they were considered as independent variables: gender, which referred to male or female; age has been described in years; the marital status comprised the situation of married/stable union, single/widow (er), divorced; training time was described in years; the achievement and type of postgraduate referred to the specialization, Residency, Master's and Doctorate; the working time at FHS was shown in years and the modality of joining the service included a contest or service rendering. Meanwhile, the second part corresponded to PHC's "access to first contact" attribute assessment, using the Primary Care Assessment Tool (PCATool) - professional version ${ }^{(3,5,19)}$.

PCATool allows the achievement of scores for PHC attributes (access to first contact, continuity service/longitudinality, coordination and completeness) and derived attributes (family approach/ orientation, community orientation and cultural competence), and overall score. In this tool, the "access to first contact" attribute is evaluated with support in nine questions, as shown in Chart 1.

Chart 1 - Questions for the assessment of the "access to first contact" attribute, according to the Primary Care Assessment Tool

\begin{tabular}{|l|}
\hline \multicolumn{1}{|c|}{ Assessment items - Access to first contact } \\
\hline A1 - Is your health service open on a Saturday or Sunday? \\
\hline $\begin{array}{l}\text { A2 - Is your health service open at least on certain days of the week, } \\
\text { until 8:00 p.m.? }\end{array}$
\end{tabular}

A3 - When your health service is open and some patient falls ill, does someone at your service see you on the same day?

A4 - When your health service is open, can patients get quick counseling over the phone when they think it's necessary?

A5 - When your health care service is closed, is there a phone number that patients can call when they get sick?

A6 - When your health service is closed on Saturdays and Sundays and some of your patients become ill, does someone from your service see you on the same day?

A7 - When your health service is closed at night and some patient becomes ill, does someone at your service see you that night?

A8 - Is it easy for a patient to be able to set a time for a health check-up (routine visit) at their health service?

A9 - On average, do patients have to wait more than 30 minutes to be seen by the physician or nurse (not counting the screening or the host)?

Source: Primary Care Assessment Tool (2001).

In the collection tool, for all the above items, there were the following answers as options: sure (value $=4)$; probably yes (value $=3$ ); probably not (value $=2$ ); certainly not (value $=1$ ); I do not know/do not remember (value $=9$ ).

The contact with the participants occurred during workshops developed by the Municipal Health Office, at which moment the research objectives were passed on, clarifications about the methodology, delivery of the Free and Informed Consent Term for reading and signature, as well as later application of the tool of data collection. This methodology used for data collection was used for all health districts, and visits to 18 Basic Health Units were also necessary for the active search of professionals who did not attend the workshops.

\section{Analysis of results, and statistics}

Descriptive and statistical analysis of the values of the items of the "access to first contact" attribute of PCATool. Data were tabulated and analyzed using SPSS software (Statistical Package for the Social Sciences), version 23. Absolute and relative frequencies were calculated for qualitative variables, as well as mean and Standard Deviation, minimum and maximum, for quantitative variables. The Mann-Whitney and Kruskal-Wallis tests were used to verify association between the sociodemographic variables. Results were expressed in tables. For all inferential procedures, a significance level of $5 \%$.

Also for the analysis, the following rules were considered: item A9 was formulated so that the higher the value (response) assigned, the lower the orientation for PHC. Thus, this item had its value inverted for: (value $4=1$ ), (value $3=2$ ), (value $2=3$ ) and (value 1=4); yet, for a respondent, when the sum of the answers "I do not know/I do not remember" or blank "missing" reached $50 \%$ or more of the total of items, the score was not calculated for this interviewee. On the other hand, when it reached less than $50 \%$ of total items, the value " 9 " was changed to the value " 2 ". This transformation is necessary to denote some characteristics of the health service not known by the interviewee.

The outcome variable was the quality of $\mathrm{PHC}$ services, whose value equal to or greater than 6.6 was considered a high PHC score, meaning a satisfactory degree of approximation with $\mathrm{PHC}^{(19)}$.

\section{RESULTS}

A total of 163 interviews were conducted with dentists $(n=40$, $24.5 \%)$, nurses $(n=63,38.6 \%)$ and physicians $(n=60,38.8 \%)$ from the FHS. The age varied from 24 to 66 years, denoting an average of 41.3 and a Standard Deviation of 10.4. The predominance of the sample was female $(n=102,62.5 \%)$ and married or in stable union $(n=120,73.6 \%)$. When questioned about the type of Higher Education Institution (HEI) where they completed the graduation, $63.8 \%$ reported having been in a public institution. A significant proportion of the sample $(n=139$; 85.3\%) accentuated postgraduate studies, predominating lato sensu specializations $(n=114,69.9 \%)$. Still, in relation to the post-graduation, the results pointed out that a significant number of professionals completed the specialization in FHS ( $n=99,60.7 \%)$. The average time the professionals were working at the FHS was 10.9 years (Standard Deviation=5.7). In turn, the length of stay in the current team showed the mean of 6.4 years (Standard Deviation $=4.4$ ). Regarding the mode of entry in the FHS, a significant proportion ( $n=107 ; 65.6 \%$ ) stated that they were admitted through a public tender (Table 1). When assessing the association between the sociodemographic characteristics of the professionals and the essential attribute (accessibility), there was no association with significance $(p>0.05)$.

The "access to first contact" attribute reached a score of 3.3 (Table 2), which was considered low degree of orientation for PHC. Nursing professionals were the ones that assigned the lowest score (3.2), and dentists, the largest (3.4). 
Table 1 - Socio-demographic classification of FHS dentists, nurses and physicians, Juazeiro do Norte, Ceará, Brazil, 2017

\begin{tabular}{|c|c|c|c|c|c|c|c|}
\hline \multirow{2}{*}{ Variables } & \multicolumn{2}{|c|}{ Dentist } & \multicolumn{2}{|c|}{ Nurse } & \multicolumn{2}{|c|}{ Physician } & \multirow{2}{*}{$p$ value } \\
\hline & $\mathbf{n}$ & $\%$ & $\mathbf{n}$ & $\%$ & $\mathbf{n}$ & $\%$ & \\
\hline \multicolumn{8}{|l|}{ Postgraduate } \\
\hline Yes & 34 & 24.5 & 62 & 44.6 & 43 & 30.9 & \multirow{3}{*}{$<0.001$} \\
\hline No & 4 & 26.7 & 0 & 0.0 & 11 & 73.3 & \\
\hline In progress & 2 & 22.2 & 1 & 11.1 & 6 & 66.7 & \\
\hline \multicolumn{8}{|l|}{ Type of postgraduate course $(n=139)$} \\
\hline Specialization & 31 & 28.0 & 55 & 49.5 & 25 & 22.5 & \multirow{4}{*}{$<0.001$} \\
\hline Residency & - & - & - & - & 12 & 100.0 & \\
\hline Master & 3 & 20.0 & 7 & 46.7 & 5 & 33.3 & \\
\hline Doctorate & - & - & - & - & 1 & 100 & \\
\hline Years working (mean \pm Standard Deviation) & \multicolumn{2}{|c|}{$11.0-3.5$} & \multicolumn{2}{|c|}{$11.6-5.5$} & \multicolumn{2}{|c|}{$10.2-6.9$} & $0.367^{3}$ \\
\hline Years at FHS (mean \pm Standard Deviation) & \multicolumn{2}{|c|}{$7.6-3.4$} & \multicolumn{2}{|c|}{$6.6-4.3$} & \multicolumn{2}{|c|}{$5.4-4.9$} & $0.008^{3}$ \\
\hline Age (mean \pm Standard Deviation) & \multicolumn{2}{|c|}{$42.2 \pm 8.6$} & \multicolumn{2}{|c|}{$39.8 \pm 7.9$} & \multicolumn{2}{|c|}{$42.4 \pm 13.5$} & $0.460^{3}$ \\
\hline \multicolumn{8}{|l|}{ Age group } \\
\hline 24 to 29 & 2 & 11.8 & 5 & 29.4 & 10 & 58.8 & \\
\hline 30 to 39 & 19 & 30.6 & 29 & 46.8 & 14 & 22.6 & \\
\hline 40 to 49 & 6 & 14.6 & 17 & 41.5 & 18 & 43.9 & $<0.001^{2}$ \\
\hline 50 to 59 & 9 & 47.4 & 7 & 36.8 & 3 & 15.8 & \\
\hline 60 or over & 1 & 9.1 & 1 & 9.1 & 9 & 81.8 & \\
\hline \multicolumn{8}{|l|}{ Gender } \\
\hline Male & 19 & 33.3 & 6 & 10.6 & 32 & 56.1 & \multirow{2}{*}{$<0.001^{1}$} \\
\hline Female & 20 & 19.6 & 55 & 53.9 & 27 & 26.5 & \\
\hline \multicolumn{8}{|l|}{ Marital status } \\
\hline Married & 33 & 27.5 & 43 & 35.8 & 44 & 36.7 & \multirow{2}{*}{$0.225^{1}$} \\
\hline Not married & 6 & 15.0 & 19 & 47.5 & 15 & 37.5 & \\
\hline \multicolumn{8}{|l|}{ Zone } \\
\hline Urban & 35 & 24.2 & 55 & 37.9 & 55 & 37.9 & \multirow{2}{*}{$0.698^{2}$} \\
\hline Rural & 5 & 27.8 & 8 & 44.4 & 5 & 27.8 & \\
\hline
\end{tabular}

Table 2 - Frequency distribution of "access to first contact" attribute items from the perspective of FHS dentists, nurses and physicians, Juazeiro do Norte, Ceará, Brazil, 2017

\begin{tabular}{|c|c|c|c|c|c|c|c|c|c|c|c|}
\hline \multirow{3}{*}{ Items* } & \multicolumn{10}{|c|}{ Access to first contact } & \multirow{3}{*}{$\begin{array}{l}\text { Score of the } \\
\text { attributed }\end{array}$} \\
\hline & \multicolumn{2}{|c|}{ Certainly yes } & \multicolumn{2}{|c|}{ Probably yes } & \multicolumn{2}{|c|}{ Probably not } & \multicolumn{2}{|c|}{ Certainly not } & \multicolumn{2}{|c|}{$\begin{array}{c}\text { I do not know/ } \\
\text { I do not remember }\end{array}$} & \\
\hline & $\mathbf{N}$ & $\%$ & $\mathbf{N}$ & $\%$ & $\mathbf{N}$ & $\%$ & $\mathbf{N}$ & $\%$ & $\mathbf{N}$ & $\%$ & \\
\hline $\mathrm{A} 1$ & - & - & - & - & 11 & 6.8 & 152 & 93.2 & - & - & \\
\hline $\mathrm{A} 2$ & - & - & - & - & 9 & 5.5 & 154 & 95.4 & - & - & \\
\hline $\mathrm{A} 3$ & 97 & 59.5 & 57 & 35.0 & 2 & 1.2 & 5 & 3.1 & 2 & 1.2 & \\
\hline A4 & 9 & 5.5 & 28 & 17.2 & 43 & 26.4 & 71 & 43.5 & 12 & 7.4 & \\
\hline A5 & 5 & 3.1 & 8 & 4.9 & 29 & 17.8 & 111 & 68.1 & 10 & 6.1 & 3.3 \\
\hline A6 & 4 & 2.5 & 9 & 5.5 & 30 & 18.4 & 118 & 72.4 & 2 & 1.2 & \\
\hline A7 & 3 & 1.8 & 7 & 4.3 & 36 & 22.1 & 114 & 70.0 & 3 & 1.8 & \\
\hline A8 & 84 & 51.5 & 64 & 39.3 & 12 & 7.4 & 3 & 1.8 & - & - & \\
\hline A9 & 16 & 9.8 & 83 & 50.9 & 35 & 21.5 & 18 & 11.0 & 11 & 6.8 & \\
\hline
\end{tabular}

Note: *A1 - Is your health service open on a Saturday or Sunday? A2 - Is your health service open at least on certain days of the week, until 8:00 p.m.? A3 - When your health service is open and some patient falls ill, does someone at your service see you on the same day? A4 - When your health service is open, can patients get quick counseling over the phone when they think it's necessary? A5 - When your health care service is closed, is there a phone number that patients can call when they get sick? A6 - When your health service is closed on Saturdays and Sundays and some of your patients become ill, does someone from your service see you on the same day? A7 - When your health service is closed at night and some patient becomes ill, does someone at your service see you that night? A8 - Is it easy for a patient to be able to set a time for a health check-up (routine visit) at their health service? A9-On average, do patients have to wait more than 30 minutes to be seen by the physician or nurse (not counting the screening or the host)?

When analyzing the items that make up this attribute, it was noticeable that the highest percentages of "certainly not" answers were focused on the questions: "Is your health service open on a Saturday or Sunday?" (93.2\%), and "Is your health service open at least on certain days of the week, until 8:00 p.m.?"(95.4\%).

In turn, high percentages of positive responses were obtained to the questions: "When your health service is open, can patients get quick counseling over the phone when they think it's necessary?" (59.5\%), and "Is it easy for a patient to be able to set a time for a health check-up (routine visit) at their health service?" (51.5\%).

\section{DISCUSSION}

Sociodemographic variables of the professionals of this study are in agreement with the results found in the literature ${ }^{(8)}$, prevailing professionals with mean age of 41.3 years, female, married or in stable union.

As for training, it shows prominence for public institutions and the increasing interest of professionals in qualifying through the postgraduate in the field of $\mathrm{FHS}^{(8,11)}$ similar to the one found in the present research. 
Regarding the time of performance as a $\mathrm{PHC}$ professional, the low average time of performance was observed, in consonance with other researches ${ }^{(8,11)}$. The short stay and high turnover of FHS professionals can lead to the fragility and difficulty of link building and trust in the relationship with users ${ }^{(13)}$.

Access to first contact is the second most studied and evaluated attribute in scientific research ${ }^{(20-21)}$. In this study, the attribute obtained a score lower than the cutoff point (6.6), thus showing the fragility of the FHS as a provider of access to health services, results that converge with other surveys conducted in different Brazilian locations. Studies are carried out within the state of Rio Grande do Norte ${ }^{(4,9)}$, Espírito Santo ${ }^{(10,13)}$, Minas Gerais ${ }^{(11)}$ and São Paulo ${ }^{(12)}$.

In the tool used (PCATool-Brazil, professional version), a subtle relationship between the expressions "access to first contact" and "ease of reaching and using the services offered"(21). This attribute, however, includes a range of processes going through several points related to embracement, humanization of the care offered, adequacy between supply and demand of services. Also, it refers to the geographical accessibility, the adequacy of schedules and the waiting time for consultation and other procedures ${ }^{(10)}$.

Corroborating with other studies ${ }^{(20,22-23)}$, it is stated that factors, such as geographic barriers, shortened hours of operation of the units, difficulties encountered to mark appointments and extended waiting time in the unit to be served, directly affect reach the low score in the "access to first contact" attribute.

It is also worth noting that the non-functioning of the health units during the night and on Saturdays and Sundays, as well as the absence of the internet and telephone network for use in the communication between professional and user, reflects in the reduction of attribute score. This reality is repeated in the different regions of Brazil ${ }^{(22-25)}$.

The present setting represents a serious limitation, since there is a large daily interval discovered for health care, which may have repercussions on the overload of other levels, such as secondary care represented by Emergency Care Units and Hospitals.

Therefore, the possibility of extending the FHS hours would solve some of the population's complaints and would contribute to reduce overcrowding in secondary care points ${ }^{(4,9)}$.

To overcome this problem of inadequacy of access to first contact, Health managers must implement organizational changes of the FHS, creation of broader hours and hiring professionals ${ }^{(4)}$. In addition, greater responsibility and commitment on the part of health professionals should be encouraged through changes in the work process ${ }^{(9-10)}$.

It should be pointed out that the organization of the Brazilian PHC services shows significant differences in the care model among the different Brazilian states, such as the South and Southeast Regions, where PCATool was applied ${ }^{(22,25-27)}$.

It is corroborated the assertion that in the Northeastern Region still has insufficient access to $\mathrm{PHC}$ services to guarantee the comprehensive care $^{(27)}$. In divergence, in some Brazilian states and in the international setting, access to first contact is evaluated as positive in terms of presence and extension ${ }^{(8,14-15,26)}$. In these settings, positive assessments are due to the existence of alternative ways of communication between professionals and users, such as internet and telephony.

There was a concerning drawing for the primary level of care, considering that it is through access to first contact that FHS professionals take actions, such as welcoming, hearing, knowing health needs, increasing the link between professionals, establishing trust, encourage adherence to health care, as well as provide accessibility, longitudinality of care and completeness.

In view of the results found, it is necessary to reformulate the public policies specific to the PHC, which includes the expansion of the hours of service for the night and weekends, as well as the establishment of communication between users and professionals through telephone and internet networks ${ }^{(28)}$. Thus, health managers can find legal bases that support the changes in the current setting of performance of FHS at the national level.

\section{Study limitations}

The research conducted only with health professionals and the absence of access to first contact assessment from the perspective of the SUS user as an actor involved in the care process can be pointed out as a possible limitation of the study. Another limitation of the study concerns the incompatibility of some of the requirements advocated by the PCATool-Brazil tool, professional version and the reality of the provision of health services by the FHS teams, specifically within the working hours. With support in this context, the need to adapt the tool for future $\mathrm{PHC}$ research is clear.

\section{Contributions to the fields of Nursing, Health or Public Policy}

The findings contribute to the nursing field, considering that this professional category composes the multidisciplinary team of the FHS and has shared responsibility in the scope of accessibility and use of health services. In terms of public health, the results generally aggregate information that makes it possible to sensitize managers and contribute to the restructuring or policy formation that can focus on PHC access to first contact.

\section{CONCLUSION}

FHS teams and management need to strengthen the accessibility and use of health services, seeking to establish communication options between professionals and users, especially on the days and times when the units remain closed. Making telephony or internet communication feasible is perhaps one of the ways for FHS to effectively become a provider of $\mathrm{PHC}$, considering the impracticability, in the current context, of changing the hours of FHS.

\section{REFERENCES}

1. Giovanella L (org.). Políticas e sistema de saúde no Brasil. 2a ed. Rio de Janeiro: Editora FIOCRUZ; 2012.1100 p.

2. Campos GWS, Guerrero AVP. Manual de práticas da atenção básica: saúde ampliada e compartilhada. $3^{a}$ ed. São Paulo: Hucitec; 2013.411 pp. 
3. Starfield B. Atenção primária: equilíbrio entre necessidades de saúde, serviços e tecnologia. Brasília: UNESCO, Ministério da Saúde; 2004,726p.

4. Araújo LUA, Gama ZAS, Nascimento FLA, Oliveira HFV, Azevedo WM, Almeida JHJB. Evaluation of the quality of primary health care from the perspective of the elderly. Ciênc Saúde Coletiva [Internet]. 2014[cited 2018 Mar 31];19(8):3521-32. Available from: http://www.scielo.br/pdf/ csc/v19n8/1413-8123-csc-19-08-03521.pdf

5. Shi L, Starfield B, Xu J. Validating the adult primary care assessment tool. J Fam Pract [Internet]. 2001 [cited 2018 Mar 31];50(2):161-4. Available from: https://www.jhsph.edu/research/centers-and-institutes/johns-hopkins-primary-care-policy-center/PCAT\%20pubs/Shi\%20 2001.pdf

6. Sumar N, Fausto MCR. Primary Health Care: the construction of an expanded concept. J Manag Prim Health Care [Internet].2014[cited 2018 Mar 31];5(2):202-12. Available from: http://www.jmphc.com.br/saude-publica/index.php/jmphc/article/viewFile/217/220

7. Marques JF, Áfio ACE, Carvalho LV, Leite SS, Almeida PC, Pagliuca LMF. Physical accessibility in primary healthcare: a step towards the embracement. Rev Gaúcha Enferm [Internet]. 2018[cited 2018 Mar 31];39:e2017-0009. Available from: http://dx.doi. org/10.1590/1983-1447.2018.2017-0009

8. Oliveira MPR, Menezes IHCF, Sousa LM, Peixoto MRG. Training and Qualification of Health Professionals: Factors Associated to the Quality of Primary Care. Rev Bras Educ Med [Internet]. 2016[cited 2018 Mar 31];40(4):547-59. Available from: http://dx.doi. org/10.1590/1981-52712015v40n4e02492014

9. Oliveira-Morais J, Morais F, Santiago C. First contact access in primary health care for children from 0 to 9 years old. Rev Pesqui Cuid Fundam [Internet]. 2017[cited 2018 Mar 31];9(3):848-56. Available from: http://www.seer.unirio.br/index.php/cuidadofundamental/article/view/5575

10. Lima EFA, Sousa Al, Primo CC. An assessment of primary care attributes from the perspective of female healthcare users. Rev LatinoAm Enfermagem [Internet]. 2015[cited 2018 Mar 31];23(3):559-9. Available from: www.scielo.br/pdf/rlae/2015nahead/pt_0104-1169rlae-0496-2587.pdf

11. Batista VCL, Ribeiro LCC, Ribeiro CDAL, Paula FA, Araújo A. Evaluation of primary health care attributes according to family health professionals. SANARE [Internet]. 2016 [cited 2019 Jan 29];15(2). Available from: https://sanare.emnuvens.com.br/sanare/article/ viewFile/1042/588

12. Gomes MFP, Fracolli LA. [Evaluation of primary health care attributes according to family health professionals]. Rev Bras Promoç Saúde [Internet]. 2018 [cited 2019 Jan 29];31(3):1-13. Available from: http://periodicos.unifor.br/RBPS/article/view/7108

13. Lima EFA, Sousa Al, Leite FMC, Lima RCD, Souza MHN, Primo CC. Evaluation of the Family Healthcare Strategy from the Perspective of Health Professionals. Esc Anna Nery [Internet]. 2016 [cited 2019 Jan 29];20(2):275-80. Available from: http://www.scielo.br/pdf/ean/v20n2/ en_1414-8145-ean-20-02-0275.pdf

14. Bresick G, Sayed AR, Grange C, Bhagwan S, Manga N, Hellenberg D. Western Cape Primary Care Assessment Tool (PCAT) study: measuring primary care organisation and performance in the Western Cape Province, South Africa. Afr J Prim Health Care Fam Med [Internet]. 2016 [cited 2019 Jan 30];8(1):1-12. Available from: http://www.scielo.org.za/pdf/phcfm/v8n1/09.pdf

15. Hu R, Liao Y, Du Z, Hao Y, Liang H, Shi L. Types of health care facilities and the quality of primary care: a study of characteristics and experiences of Chinese patients in Guangdong Province, China. BMC Health Serv Res [Internet]. 2016 [cited 2019 Jan 30]2;16(a):335. Available from: https://www.ncbi.nlm.nih.gov/pubmed/27484465

16. Von Elm E, Altman DG, Egger M, Pocock SJ, PC Gotzsche, Vanderbroucke J. for the STROBE Initiative. The Strengthening the Reporting of Observational Studies in Epidemiology (STROBE) statement: guidelines for reporting observational studies. J Clin Epidemiol [Internet]. 2008 [cited 2019 Feb 30]; 61(4):344-49. Available from: https://www.ncbi.nlm.nih.gov/pubmed/18313558

17. Juazeiro do Norte. Secretaria Municipal de Saúde. Departamento da Atenção Básica. Plano municipal de Saúde. Juazeiro do Norte: Secretaria Municipal de Saúde; 2018. 95p.

18. Instituto Brasileiro de Geografia e Estatística-IBGE. Estimativas populacionais para os municípios e para as Unidades da Federação brasileiros. Rio de Janeiro: IBGE; 2017. Available from: http://biblioteca.ibge.gov.br/visualizacao/livros/liv100923.pdf

19. Ministério da Saúde (BR). Secretaria de Atenção em Saúde. Departamento de Atenção Básica. Manual do instrumento de avaliação da atenção primária à saúde: primary care assessment tool pcatool- Brasil. Brasília: Ministério da Saúde; 2010. 80p.

20. Prates ML, Machado JC, Silva LS, Avelar PS, Prates LL, Mendonça ET, et al. Performance of primary health care according to PCATool instrument: a systematic review. Ciênc Saúde Coletiva[Internet]. 2017[cited 2018 Mar 31];22(6):1881-93. Available from: http://www.scielo. $\mathrm{br} / \mathrm{pdf} / \mathrm{csc} / \mathrm{v} 22 \mathrm{n6} / \mathrm{en} \_1413-8123-\mathrm{csc}-22-06-1881 . p d f$

21. Ministério da Saúde (BR). Portaria n 4.279, de 30 de dezembro de 2010. Estabelece diretrizes para a organização da Rede de Atenção à Saúde no âmbito do Sistema Único de Saúde - SUS. Diário Oficial da União, 31 dez 2010; Seção 1. p. 88.

22. Ferreira VD, Oliveira JM, Maia MAC, Santos JS, Andrade RD, Machado GAB. Assessment of Primary Healthcare attributes in one Municipality of Minas Gerais State. Esc Anna Nery [Internet]. 2016[cited 2018 Mar 31];20(4):e20160104. Available from: http://www.scielo.br/pdf/ean/ v20n4/en_1414-8145-ean-20-04-20160104.pdf

23. Gontijo TL, Duarte AGS, Guimarães EAA, Silva J. Evaluation of primary care: the point of view of users. Saúde Debate [Internet]. 2017[cited 2018 Mar 31];41(114):741-52. Available from: https://doi.org/10.1590/0103-1104201711406

24. Penso JM, Périco E, Oliveira MMC, Strohschoen AAG, Carreno I, Rempel C. Evaluation of Primary Health Care using the PCATool-Brazil Instrument. Rev Bras Med Fam Comunidade [Internet]. 2017[cited 2018 Mar 31];12(39):1-9. Available from: http://dx.doi.org/10.5712/ rbmfc12(39) 1212 
25. Santos NCCB, Vaz EMC, Nogueira JA, Toso BRGO, Collet N, Reichert APS. Presence and extent of primary care characteristics under different models for children's healthcare. Cad Saúde Pública [Internet]. 2018[cited 2018 Mar 31];34(1):e00014216. Available from: http://www.scielo. $\mathrm{br} / \mathrm{pdf} / \mathrm{csp} / \mathrm{v34n1/1678-4464-csp-34-01-e00014216.pdf}$

26. Turci MA, Lima-Costa MF, Macinko J. The influence of structural and organizational factors on the performance of primary health care in Belo Horizonte, Minas Gerais State, Brazil, according to nurses and managers. Cad Saúde Pública [Internet]. 2015[cited 2018 Mar 31];31(9):194152. Available from: http://www.scielo.br/pdf/csp/v31n9/0102-311X-csp-31-9-1941.pdf

27. Silva NA, Silva AS, Silva ARV, Araújo TME, Rebouças CBA, Nogueira LT. Primary care assessment from a male population perspective. Rev Bras Enferm [Internet]. 2018;71(2):255-63. Available from: http://www.scielo.br/pdf/reben/v71n2/0034-7167-reben-71-02-0236.pdf

28. Pedraza DF, Nobre AMD, Albuquerque FJB, Menezes TN. Accessibility to Basic Family Health Units from the perspective of the elderly. Ciênc Saúde Coletiva [Internet]. 2018[cited 2018 Mar 31];23(3):923-33. Available from: http://www.scielo.br/pdf/csc/v23n3/1413-8123csc-23-03-0923.pdf 